\section{Klopidogrel og \\ protonpumpehemmere}

Protonpumpehemmere hemmer enzymet cytokrom P-450 2C19, som er nødvendig for omdanningen av klopidogrel til dens aktive metabolitt. I en kanadisk flettet pasient-kontroll-studie fant man at pasienter som sto på klopidogrel etter hjerteinfarkt og samtidig tok protonpumpehemmere, hadde $ø$ kt risiko for nytt infarkt innen 90 dager etter det første infarktet (justert OR 1,3; $95 \%$ KI 1,03-1,57) (CMAJ 2009; 180 : 713-8). For pantoprazol, som ikke hemmer det nevnte enzymet, fant man ikke denne $ø$ kte risikoen.

\section{Fysisk aktivitet i skolen - påvirkning på fedme?}

Fedme hos barn er et $ø$ kende problem. Prevalenstall fra USA har vist en tredobling av overvektige barn siden 1970. En kanadisk forskergruppe har gjennomført en metaanalyse basert på randomiserte kontrollerte studier og kontrollerte kliniske studier av hvordan økt fysisk aktivitet i skolen påvirker barns kroppsmasseindeks (CMAJ 2009; 180: 719-26).

Data fra 15 studier med til sammen 13000 barn og studielengde på 6-36 måneder ble analysert. Man fant ingen signifikant forskjell i endring av kroppsmasseindeks mellom intervensjonsgruppen og kontrollgruppen (veiet gjennomsnitt $-0,05 \mathrm{~kg} / \mathrm{m}^{2} ; 95 \% \mathrm{KI}-0,19-0,10$ ).

\section{Konservativ behandling av skuddskader i lever}

En sørafrikansk prospektiv protokollbasert studie tok for seg innkomne skuddskader til et sykehus i Cape Town i perioden 2004-08 (Ann Surg 2009; 249: 653-6). Totalt 63 pasienter med skuddskadet lever ble selektert til konservativ behandling, mens 132 måtte opereres akutt. Man undersøkte antall ligged øgn, komplikasjoner, overlevelse og behovet for senere laparotomi blant de konservativt behandlede.

Fem pasienter gjennomgikk senere laparotomi, hvilket medfører en suksessrate på $92 \%$. Ingen pasienter i gruppen omkom. På selekterte leverskader etter skyting er det trygt, effektivt og gjennomførbart å behandle konservativt, konkluderer forfatterne.

\title{
Store forskjeller i sfinkterruptur mellom sykehus
}

Det var nesten fire ganger så stor risiko

for sfinkterruptur ved sykehuset som

hadde høyest insidens sammenliknet

med sykehuset som hadde lavest insi-

dens. Det viser en norsk studie.

Tidligere undersøkelser har vist store insidensforskjeller i sfinkterrupturer mellom nordiske land. Vi ønsket i denne prospektive studien å sammenlikne insidens av sfinkterrupturer ved ikke-instrumentelle vaginale forløsninger ved fem norske sykehus av ulik størrelse (1). Alle kvinner som fikk en sfinkterruptur under vaginalforløsning ledet av jordmor, ble registrert. Kjente risikofaktorer ble sammenliknet, og rupturene ble klassifisert på enhetlig måte i partielle og totale rupturer.

Det var signifikante insidensforskjeller mellom sykehusene. Høyest insidens var $4,7 \%$, lavest var $1,3 \%$. Det var ingen samvariasjon mellom antall fødsler og sfinkterrupturinsidens. Det var heller ingen forskjeller mellom sykehusene ved sammenlikning av gestasjonslengde, fødselsvekt, fødselspresentasjon (hodeleie/seteleie), tidligere keisersnittforløsning, mors alder, varighet av andre forløsningsstadium, tidligere sfinkterruptur eller skulderdystoki. Uventet var det både signifikant flere induksjoner og oxytocinstimuleringer $i$ andre stadium ved sykehuset som hadde færrest sfinkterrupturer. Andel jordmødre som oppga at de brukte støtteteknikk av perineum under forløsningen var lik ved de to sykehusene med størst insidensforskjell.

Vi fant ingen annen sannsynlig forklaring på den store forskjellen i sfinkterruptur enn at måten støtteteknikk er utført på, er tilfeldig og varierende. Vi mener det bør fokuseres på systematisk støtteteknikkopplæring blant jordmødre for bedre å kunne unngå sfinkterrupturer. Etter at studien ble avsluttet, ble slik opplæring igangsatt ved flere av sykehusene, og foreløpige registreringer har vist signifikant bedring av insidenstallene.

\section{Annelill Valbø}

a-valboe@online.no

Kvinneklinikken

Sykehuset Asker og Bærum

\section{Litteratur}

Valbø A, Gjessing L, Herzog C et al. Anal sphincter tears at spontaneous delivery: a comparison of five hospitals in Norway. Acta Obstet Gynecol Scand 2008; 87: 1176-80.

\section{Lite samsvar mellom knesmerte og MR-funn}

\section{Meniskskader på MR er et vanlig funn hos middelaldrende og eldre, både med og uten knesmerter. Dette viser en amerikansk studie.}

MR er blitt en vanlig undersøkelse ved knesmerter. En amerikansk studie tok for seg et tilfeldig utvalg på 991 personer i alderen 50-90 år. Disse ble spurt om knesmerte, og det ble tatt røntgen og MR av høyre kne (1). Prevalensen av menisklesjoner i høyre kne var 35\% (95\% KI 32-38) når man så på hele utvalget, og den økte med økende alder. Flertallet av menisklesjonene (60\%) ble funnet hos personer uten noen form for smerte eller stivhet siste måned.

Prevalensen av menisklesjoner på MR var signifikant høyere i gruppen med røntgenologisk påvist kneleddsartrose enn gruppen uten $(82 \%$ mot $25 \%, \mathrm{p}<0,001)$, men det var ingen sammenheng mellom smerte/stivhet og MR-funn i artrosegruppen.

- Denne studien bekrefter tidligere norske og internasjonale studier, sier pro- fessor i ortopedi Lars Engebretsen ved Ullevål universitetssykehus.

- Patologiske MR-funn er vanlige også hos personer uten kneplager. MR bør derfor ikke være første undersøkelse ved knesmerter hos pasienter over 50 år. Dersom kneet låser seg, kan det skyldes en løs bruskbeinbit eller en meniskskade, og da er det aktuelt med kirurgi.

Knesmerter hos eldre skyldes oftest artrose, og meniskskaden er et ledd i den degenerative prosessen. Meniskkirurgi alene vil da ikke hjelpe. Et vanlig røntgenbilde i vektbærende stilling vil bedre enn MR kunne si noe om graden av artrose. Egne beregninger tyder på at kostnadene ved unødvendige MR-undersøkelser utgjør opptil 50 millioner kroner årlig, sier Engebretsen.

\section{Mette Sagsveen}

msagsveen@yahoo.com

Tidsskriftet

\section{Litteratur}

1. Englund M, Guermazi A, Gale D et al. Incidental meniscal findings on knee MRI in middle-aged and elderly persons. N Engl J Med 2008; 359: 1108-15. 